\title{
ポリ塩化ビニルをマトリックスとした液膜型過塩素酸イオン選択性 電桖を用いる過塩䒺酸イオンのゼフィラミンによる沈殿電位差滴定
}

\author{
田 村 徹 ${ }^{\circledR *}$ ，片岡 正光**
}

(1984 年 5 月 4 日受理)

\begin{abstract}
トリス（バソフェナントロリン)鉄(II) と過塩素酸イオンのイオン対を感応物質とするボリ塩化ビニ 儿固化膜型過塩素酸イオン選択性電極を試作し，その電極特性を検討するとともに，同電極を指示電極 に用い第四級フンモニウム塩のゼフィラミンを滴定剂として沈殿電位差滴定を行った。作製した電極 は $10^{-1} \sim 10^{-6} \mathrm{M}$ の過塩素酸イオンにほほ Nernst 応答し, 目的イオン濃度 $10^{-4} \mathrm{M}$ 溶液の電位は $\mathrm{pH}$ 1〜13 の範囲で一定であった．滴定においては，24.87〜 $74.60 \mathrm{mg}$ の過塩素酸イオンを $0.6 \%$ 以下の 相対誤差と $0.2 \%$ 以下の相対標準偏差で簡便かつ迅速に定量が可能であった. 実試料で過塩素酸イオ ンと共存することの多い硝酸イオンは正の誤差を与えるとともに, 終点付近での電位飛躍を抑元, 終点 の判読を困難にしたが，酷酸酸性で 粉末亜鉛を加元加熱し，硝酸イオンを選択的に還元することによ り，その妨害を除去するととが可能であった．本法を用いて実試料を分析した結果は，JIS 法による分 析結果と良い一致を示した。
\end{abstract}

\section{1 緒言}

過塩素酸イオンの定量法は, 還元骫を用いて塩化物イ オンに還元し定量する間接法と, 過塩素酸イオンをその まま定量する直接法の二つに大別される.

間接法には, アルカリ融解により塩化物イオンに還元 し塩化銀として重量分析する JIS 法1), 硫酸酸性中で水 素化チタンにより塩化物イオンとし銀滴定法により定量 する方法2), 三塩化チタンにより還元後, 過剩の試薬を 鉄ミョウバンで逆滴定する方法3)などがある.

直接法は主に過塩素酸イオンが陽イオン性色素や各種 のオニウムイオンとイオン対を形成することを利用した あのである．溶媒抽出法としてはメチレンブルー4) ある いは 1,10-フェナントロリン鉄(II) $)^{5)}$ と過塩素酸イオン のイオン対をニトロベンゼンに抽出し吸光光度法により 定量する方法があり, テトラフェニルアルソニウムやテ トラフェニルホスホニウムなどのオニウムイオンと過塩 素酸イオンとの沈殿生成反応を利用した重量分析6)， あ

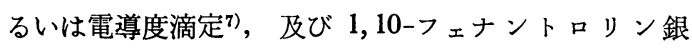
（I）と過塩素酸イオンの 沈殿生成反応を利用した電導

* 北海道整察本部科学捜査研究所：060 北海道札幌 市中央区北 2 条西 6 丁目

** 北海道大学理学部化学科 : 060 北海道札幌市北区 北 10 条西 8 丁目
度滴定法8)がある.

一方，イオン選択性電極を用いた定量分析に関する研 究は最近ますます増加の傾向にあるが，同電極を電位差 滴定の終点指示電極とする方法は, 試料溶液が着色して いたり，適当な指示薬がないような場合には特に有効で あり，分析の自動化の面からも好ましい。過塩素酸イオ ン選択性電極は既に数社から市販されており, 又同電極 の試作に関する報告9) 16) む数多い. しかし, 同電極の 応用に関する研究は少なく, 塩化テトラフェニルアルソ ニウムを滴定剤とする過塩素酸イオンの沈殿電位差滴定 の指示電極とした Smith ら ${ }^{17)}$ あるい Baczuk ら ${ }^{18) の ~}$ 研究が見受けられる程度である.

著者らは，第四級アンモニウム塩であるゼフィラミ ン（塩化ベンジルジメチルテトラデシルアンモニウム, $\mathrm{Zeph}{ }^{+} \mathrm{Cl}^{-}$) が過塩素酸イオンとイオン対を形成し，水 溶液中で沈殿することを利用して, 試作した過塩素酸イ オン選択性電極を指示電極に用い, 過塩素酸イオンをゼ フィラミンにより，簡便かつ迅速に滴定した。硝酸イオ ンの共存は妨害となるが，その除去方法についても検討 を加えた、な技新たに試作した過塩素酸イオン選択性電 極は, トリス (バソフェナントロリン) 鉄(II) と過塩素 酸イオンのイオン対を感応物質とするポリ塩化ビニル (PVC) 固化膜型のものである. 


\section{2 実験}

\section{1 試 薬}

過塩素酸カリウム溶液 $(50 \mathrm{mM}): 110^{\circ} \mathrm{C}$ で 3 時間加熱 乾燥した和光純薬工業製特級過塩素酸カリウム $6.9276 \mathrm{~g}$ を精ひょうし，脱イオン水に溶解して $1 \mathrm{dm}^{3}$ とした。

ゼフィラミン溶液 $(50 \mathrm{mM})$ : 同仁化学研究所製, ド 一タイト試薬䄪 $20.6 \mathrm{~g}$ を採り, 脱イオン水に溶解して $1 \mathrm{dm}^{3}$ とし，濃度は銀電極を用いて $50 \mathrm{mM}$ 硝酸銀標 準溶液で標定した。

パソフェナントロリン (Bphen) は和光純薬工業製特 級を，粉末亜鉛は同一級をそのまま用い，PVC 粉末は 和光純薬工業製の重合度 1100 のものを使用した．その 他の試薬はすべて特級品を使用した。

\section{$2 \cdot 2$ 装}

電位は Corning $109 \mathrm{pH}$ メーター（測定精度, \pm 0.1 $\mathrm{mV})$ によって測定し， 日立レコーダー 056 型で記録 した。 参照電極としては, 堀場 2010-05AT シングルジ ヤンクショソ型飽和カロメル電極を使用した．電位差滴 定には，平沼自動滴定装置 RAT-11 を使用した。

\section{$2 \cdot 3$ 電極感応膜の作製}

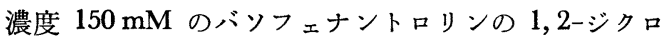
ロエタン溶液 $10 \mathrm{ml}$ を分液漏斗に採り, $50 \mathrm{mM} \mathrm{Mohr}$ 氏塩 $\left\{\mathrm{FeSO}_{4} \cdot\left(\mathrm{NH}_{4}\right)_{2} \mathrm{SO}_{4} \cdot 6 \mathrm{H}_{2} \mathrm{O}\right\}$ 溶液 $10 \mathrm{ml}$ 及び 0.5 $M$ 過塩素酸アンモニウム溶液 $10 \mathrm{ml}$ を加え, 30 分間振 り混ぜる. 有機相は $\mathrm{Fe}(\mathrm{Bphen})_{3}\left(\mathrm{ClO}_{4}\right)_{2}$ の抽出により 赤色を発する. 30 分静置した後, 有機相を分取し, 少 量の無水硫酸ナトリウムを加えて脱水する.

この抽出液をそのまま，あるいは希釈して $1 \mathrm{ml}$ 採り， $12.5 \%$ PVG のテトラヒドロフラン溶液 $2 \mathrm{~g}$ と混合し た後, 更に可塑剤としてフタル酸ジオクチル $0.5 \mathrm{~g}$ を加 える.この混合液をガラス板上に流し移し，48 時間静 置して溶媒を揮散させ，厚さ $0.2 \sim 0.3 \mathrm{~mm}$ の赤色の感 応膜を得た。

\section{4 電池の構成及び電位測定}

2.3 で得た感応膜を PVC 管 (外径 $9 \mathrm{~mm}$, 内径 7 $\mathrm{mm})$ の下端に PVGのテトラヒドロフラン溶液を接着剤 としてはり付ける.内部参照溶液として $50 \mathrm{mM}$ の塩化
ナトリウムを含む $50 \mathrm{mM}$ の過塩素酸 ナトリウム溶液 を，内部参照電極として銀-塩化銀電極を使用し電極を 作製した．作製した電極を含む電池の構成を下に示す.

この電池の起電力は Nicolsky-Eisenman 式 ${ }^{19)}$ により 次のように表される.

$$
E=E_{0}-(R T / F) \ln \left(a_{\mathrm{ClO}_{4}}-+\sum_{j} K_{\mathrm{j}} a_{\mathrm{j}} 1 / z_{\mathrm{j}}\right)
$$

ここで $a_{\mathrm{ClO}_{4}}-$ 及び $a_{\mathrm{j}}$ は目的及び共存イオンの活量, $K_{\mathrm{j}}$ は $\mathrm{j}$ 種イオンの選択係数， $z_{\mathrm{j}}$ はその電荷の絶対值で ある.なお，電極電位の 測定は室温 $20 \sim 25^{\circ} \mathrm{C}$ で行っ た。

\section{5 滴定操作}

過塩素酸イオン 25〜 75 mg を含む試料溶液を $50 \mathrm{ml}$ ビーカーに採り，水を加えて 全量を $30 \mathrm{ml}$ とし，作製 した電極と参照電極を浸して，マグネチックスターラー でかき混ぜながら， $50 \mathrm{mM}$ ゼフィラミン溶液で電位差 滴定を行ら．記録計感度はフルスパン $240 \mathrm{mV}$, チャー 卜紙送り速度 $20 \mathrm{~mm} \mathrm{~min}^{-1}$, 滴定速度は $1.5 \mathrm{ml} \mathrm{min}^{-1}$ で開始し，予想される終点の約 $1 \mathrm{ml}$ 手前から $0.03 \mathrm{ml}$ $\min ^{-1}$ に切り換えた.

\section{3 結果}

\subsection{PVG 膜中のイオン対量の検討}

PVG 膜中の $\mathrm{Fe}(\mathrm{Bphen})_{3}\left(\mathrm{GlO}_{4}\right)_{2}$ の量を変化させて イオン電極を作製し，その検量線から最適量を検討し た. Fig. 1 に示すよらに, PVC 膜中のイオン対量が重 量\%で 0.77 7.7\% のとき, 過塩素酸イオン濃度 $10^{-1}$ 〜 $10^{-6} \mathrm{M}$ の範用で 10 倍の濃度変化に対する電位変化が 54〜 55 mV とほぼ Nernst 応答を示した.イオン対の 量を減少させていくと，電位の安定性が覀くなる傾向が あった。これは感応膜の電導性が減少するためと考えら れ，従って以後の実験では電位の最も安定な $7.7 \%$ の ものを使用した.

\section{2 起電力の経時変化及び応答特性}

電極を試料溶液に浸し, 40 分間その起電力を測定し

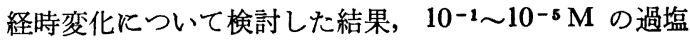

$$
\begin{array}{l|l|l|l|}
\mathrm{Ag} / \mathrm{AgCl} & \begin{array}{l}
\text { Reference soln., } \\
50 \mathrm{mM} \text { in } \mathrm{NaClO}_{4}, \\
50 \mathrm{mM} \text { in } \mathrm{NaCl}
\end{array} & \begin{array}{l}
\mathrm{ClO}_{4}^{-} \text {sensitive } \\
\mathrm{PVC} \text { membrane }
\end{array} & \begin{array}{l}
\text { Sample soln. } \\
\text { containing } \mathrm{ClO}_{4}^{-}
\end{array}
\end{array} \mid \mathrm{SCE}
$$




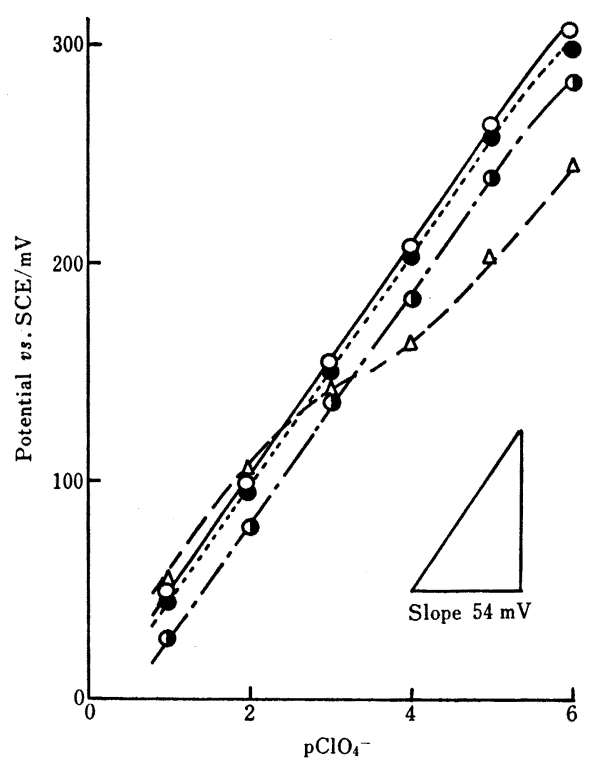

Fig. 1 Effect of $\mathrm{Fe}(\text { Bphen })_{3}\left(\mathrm{ClO}_{4}\right)_{2}$ content in poly (vinyl chloride) membrane $\mathrm{Fe}(\text { Bphen })_{3}\left(\mathrm{ClO}_{4}\right)_{2}$ content : $\bigcirc$ 7.7, 1.54, 0.77, $\triangle 0.077(w / w) \%$

素酸イオン濃度では直ちに一定の電位を示し, その経時 変化はほとんどなかったが，10-6 $\mathrm{M}$ 溶液では時間とと あに正の方向へと変化した.

又, 試料溶液に高濃度の過塩素酸イオン溶液を加劣, 濃度を $10^{-5} \mathrm{M}$ から $10^{-4} \mathrm{M}$ に, 及び $10^{-4} \mathrm{M}$ から $10^{-3}$ M に変化させた場合, いずれる $90 \%$ 応答に要する時 間は 5 秒以内であった.

\section{3 起電力の $\mathbf{p H}$ 依存性}

塩化ナトリウムによってイオン強度を 0.1 に保った $0.1 \mathrm{mM}$ 過塩素酸ナトリウム溶液に, 同一濃度の過塩素 酸イオンを含む塩酸及び水酸化ナトリウム溶液を加えて $\mathrm{pH}$ を調節し, 起電力の $\mathrm{pH}$ 依存性について検討した。 Fig. 2 に示すように, $0.1 \mathrm{mM}$ 過塩素酸イオンに対す る起電力は $\mathrm{pH}$ 1〜13 の範囲で一定であり, 本電極は 広い $\mathrm{pH}$ 範囲での使用が可能である.

\section{4 通択性}

測定溶液中の 共存イオンを高濃度一定に保ち, 過塩 素酸イオン濃度を0.2 2 $\mathrm{mM}$ に変化させる Rechnitz $ら^{20)}$ の混合溶液法により, 本電極に対する種々の陰イオ ンの選択係数を算出した. この計算に用いたイオンの活 量は Kielland21) の表より求めた。 Table 1 に示すよ

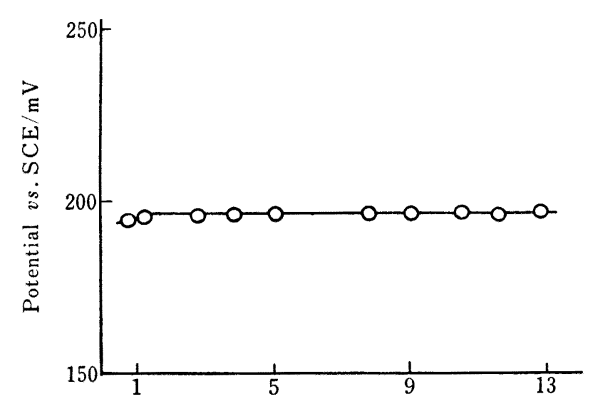

$\mathrm{pH}$

Fig. 2 Electrode response as the function of $\mathrm{pH}$ Concentration of perchlorate : $0.1 \mathrm{mM}$; Ionic strength : $0.1 \mathrm{M}$ with $\mathrm{NaCl}$; Temp. $22^{\circ} \mathrm{C}$

Table 1 Selectivity coefficients for perchlorate ion-selective electrode

\begin{tabular}{lc|lc}
\hline \multicolumn{1}{c}{ Anion } & $-\log K_{\mathrm{j}}$ & \multicolumn{1}{c}{ Anion } & $-\log K_{\mathrm{j}}$ \\
\hline $\mathrm{CH}_{3} \mathrm{COO}^{-}$ & 3.72 & $\mathrm{SO}_{4}{ }^{2-}$ & 3.06 \\
$\mathrm{HCO}_{3}{ }^{-}$ & 3.47 & $\mathrm{NO}_{3}{ }^{-}$ & 3.00 \\
$\mathrm{Cl}^{-}$ & 3.46 & $\mathrm{CO}_{3}{ }^{2-}$ & 2.74 \\
$\mathrm{NO}_{2}{ }^{-}$ & 3.42 & $\mathrm{ClO}_{3}{ }^{-}$ & 2.66 \\
$\mathrm{BrO}_{3}{ }^{-}$ & 3.32 & $\mathrm{I}^{-}$ & 1.70 \\
$\mathrm{IO}_{3}{ }^{-}$ & 3.29 & $\mathrm{SCN}^{-}$ & 1.00 \\
$\mathrm{Br}^{-}$ & 3.25 & $\mathrm{IO}_{4}^{-}$ & 0.19 \\
$\mathrm{OH}^{-}$ & 3.19 & & \\
\hline
\end{tabular}

らに, 本電極は過ヨウ素酸イオンには過塩素酸イオンと 同程度に感応し, ほかにチオシアン酸イオン, ヨウ化物 イオンの妨害が大きい.

\section{5 ゼフィラミンによる 過塩素酸イオンの 沈殿電位 差滴定}

本電極を指示電極に用い，ゼフィラミンを滴定剤とし て過塩素酸イオンを滴定した. Fig. 3 は $50 \mathrm{mM}$ 過塩 素酸カリウム溶液を $50.39 \mathrm{mM}$ のゼフィラミン溶液で 滴定した際の滴定曲線である. 終点付近では過塩素酸イ オン濃度が希薄となるため, 電極の応答が遅く, 従って ゼフィラミン溶液の滴加速度を小さくする必要があり, 又コロイド状の沈殿が生成し，粘度が高くなるのでかき 混ぜは十分に行わなければならない, 滴定では, ゼフィ ラミン溶液の 1 回の滴加量を $0.03 \mathrm{ml}$ と一定に保ち, 電位飛躍が最大のところを終点とした. 終点での電位飛 躍は約 $10 \mathrm{mV} / 0.03 \mathrm{ml}$ であり, 終点は当量点とほぼ一 致した。

過塩素酸イオンの $24.87 \sim 74.60 \mathrm{mg}$ を含む試料溶液 を定量した結果, Table 2 に示すように $0.6 \%$ 以下の 相対誤差と $0.2 \%$ 以下の相対標準偏差で定量が可能で 


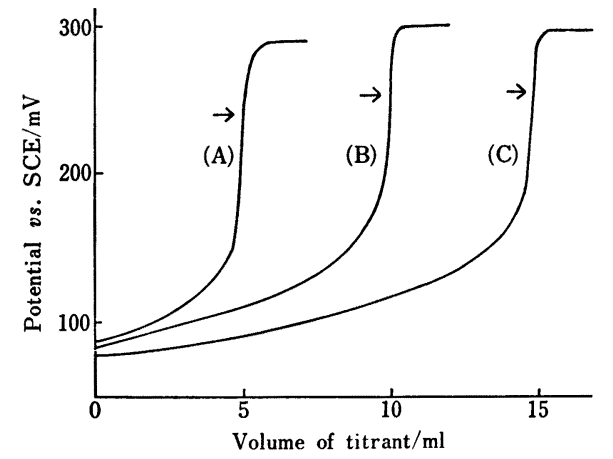

Fig. 3 Potentiometric titration curves of $50 \mathrm{mM}$ potassium perchlorate solution with 50.39 mM Zephiramine solution

$\mathrm{KClO}_{4}$ solution taken: (A) $5.0 \mathrm{ml}$, (B) $10.0 \mathrm{ml}$, (C) $15.0 \mathrm{ml}$; Arrows indicate the end points.

Table 2 Determination of perchlorate ion

\begin{tabular}{cccc}
\hline Taken/mg & Found $t / \mathrm{mg}$ & Error, \% & R. S. D., \% \\
\hline 24.87 & 25.01 & +0.56 & 0.2 \\
49.73 & 49.74 & +0.02 & 0.2 \\
74.60 & 74.78 & +0.24 & 0.1 \\
\hline
\end{tabular}

$\dagger$ Mean value of five determinations

あった。

\section{6 滴定に及ぼす共存イオンの影響}

過塩素酸イオンの $49.73 \mathrm{mg}$ を含む溶液を電位差滴定 する際の共存イオンの影響について検討した。な和検討 した陰イオンは実際の試料中で共存する可能性のあるイ オンに限ったため, Table 1 に示した選択係数の值か ら大きな妨害が予想される過ヨウ素酸, チオシアン酸, ヨウ化物イオンは検討していない. Table 3 に示すよ らに, 塩化物, 酢酸, 硫酸イオンはモル比で過塩素酸イ オンの 100 倍量共存しても, ほとんど妨害しない。亜 硝酸, 臭化物, 硝酸, 塩素酸イオンの共存は, 終点付 近での電位飛躍を抑え，正の誤差を与えるとともに， Table 3 の表示值以上の 共存は終点の判定を困難にし た.

\section{7 硝酸イオンの除去}

硝酸塩は酸素供給剤として, 工業用爆薬であるカーリ ットや煙火などの過塩素酸塩を含む製品に添加されてい る. 先に述べたように, 硝酸イオンの共存は本法による 過塩素酸イオンの定量の妨害となり, 等モル量の共存で 約 $1 \%$ の正の䛊差を与え, それ以上共存すると終点で の電位飛躍が小さく終点の判定は困難となったので, そ
Table 3 Effect of diverse ions on the determination of perchlorate ion

\begin{tabular}{llccc}
\hline \multicolumn{1}{c}{ Ion } & Added as & $\begin{array}{c}\text { Ion/ClO } \\
\text { molar ratio }\end{array}$ & $\begin{array}{c}\text { Found/ } \\
\mathrm{mg}\end{array}$ & $\begin{array}{c}\text { Error, } \\
\%\end{array}$ \\
\hline $\mathrm{Cl}^{-}$ & $\mathrm{NaCl}$ & 100 & 49.64 & -0.2 \\
$\mathrm{SO}_{4}{ }^{2-}$ & $\left(\mathrm{NH}_{4}\right)_{2} \mathrm{SO}_{4}$ & 100 & 49.44 & -0.6 \\
$\mathrm{CH}_{3} \mathrm{COO}^{-}$ & $\mathrm{CH}_{3} \mathrm{COONa}$ & 100 & 49.49 & -0.5 \\
$\mathrm{NO}_{2}{ }^{-}$ & $\mathrm{NaNO}_{2}$ & 20 & 49.89 & +0.3 \\
$\mathrm{Br}^{-}$ & $\mathrm{KBr}$ & 3 & 49.99 & +0.5 \\
$\mathrm{NO}_{3}{ }^{-}$ & $\mathrm{NaNO}$ & 1 & 50.18 & +0.9 \\
$\mathrm{ClO}_{3}{ }^{-}$ & $\mathrm{KClO}_{3}$ & 0.1 & 50.00 & +0.5 \\
\hline $\mathrm{ClO}_{4}{ }^{-}$taken $: 49.73 \mathrm{mg}$ & & &
\end{tabular}

の除去方法を検討した.

硝酸イオンは酸性条件下で粉末亜鉛を添加することに より亜硝酸イオンに還元されることが知られており, 硝 酸イオンの定量法 ${ }^{22)}$ とて利用されている. しかし,こ の反応はそのままでは還元率が低いので，更に強い還元 条件として加熱する方法をとった.すなわち, 硝酸イオ ンが共存する溶液に, 酶酸及び粉末亜鉛を加劣, ホット プレート上で加熱する．この溶液を室温まで椧却し被滴 定溶液とする．この方法では硝酸イオンのみが選択的に 還元され，又未反応の粉末亜鉛は滴定の妨害とはならな いので，操作が簡便である. Fig. 4 はモル比で 5 倍量 の硝酸イオンを含む $50 \mathrm{mM}$ 過塩素酸 カリウム溶液 10

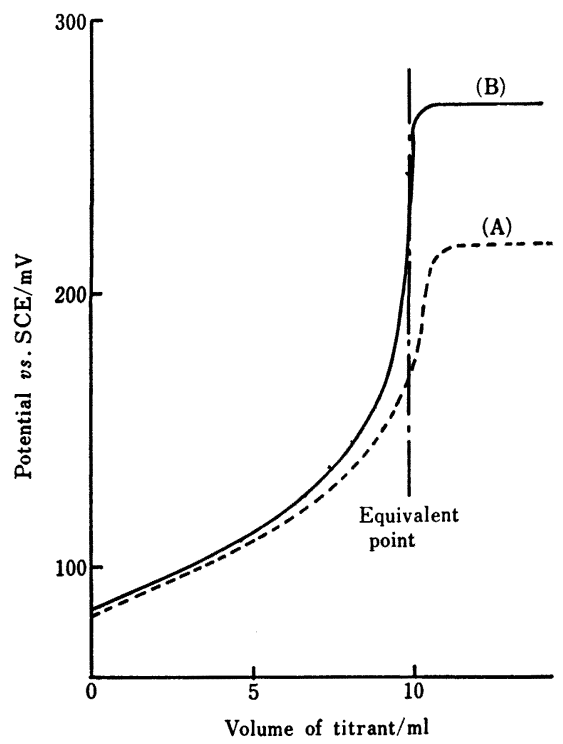

Fig. 4 Effect of nitrate ion reduction on the potentiometric titration of perchlorate ion with $50.39 \mathrm{mM}$ Zephiramine

Sample : $10 \mathrm{ml}$ of $50 \mathrm{mM} \mathrm{KClO}$, containing $250 \mathrm{mM}$ $\mathrm{NaNO}_{3}$; (A) : Before reduction of nitrate ion; (B) : After reduction of nitrate ion 
$\mathrm{ml}$ の硝酸イオン還元前及び還元後の 滴定曲線を示す. 硝酸イオンを還元除去することによって，電位飛躍は回 復し, 終点は明りょらとなった.

硝酸イオンの妨害の除去に必要な酢酸, 粉末亜鉛, 加 熱時間について検討したところ， $2 \mathrm{M}$ 酢酸 $3 \mathrm{ml}$ 以上, 粉末亜鉛 $0.5 \mathrm{~g}$ 以上, 加熱時間 10 分以上で妨害を除去 できた.しかし, 酢酸の添加量が増加するにつれて, 終 点付近での電位飛躍は減少する傾向にあったため, その 添加量を必要最少量とした.

モル比で 5 倍量の硝酸イオンが共存し， $49.73 \mathrm{mg}$ の 過塩素酸イオンを含む溶液に, $2 \mathrm{M}$ 酢酸 $3 \mathrm{ml}$, 粉末亜 鉛 $1 \mathrm{~g}$ を加え, 10 分間加熱して, 硝酸イオンを還元除 去した後, 本法により過塩素酸イオンを 5 回定量した結 果は $95 \%$ 信頼限界で $49.65 \pm 0.18 \mathrm{mg}$, 相対標準偏差 は $0.3 \%$ であった.

\section{8 実試料への応用}

過塩素酸塩を含も試料として, 自動車への装備が義務 付けられている緊急保安炎筒の伝火薬部分, トドなどの 水産害獣の威かく用として市販されている 商品名：“轟 音玉”, 及び工業用爆薬のカーリットについて, 各試料 中の過塩素酸イオンを本法により定量した. その結果を JIS 法による結果と比較して Table 4 に示す. 両法の 定量值の差は $0 \sim 1 \%$ 程度で良い一致を示した。なお， 硝酸塩を含有しているカーリット中の過塩素酸イオンの 定量については, 硝酸イオンを還元した後, あるいはそ のまま定量する方法の両法について行ったが, 硝酸イオ ンの含有量が少ないため, 定量値に差は認められなか った.

本法は, 1 試料の滴定に要する時間は 20 分程度で, JIS 法と比較して数段, 簡便迅速な方法である.

Table 4 Determination of perchlorate in explosives

\begin{tabular}{|c|c|c|c|}
\hline \multirow{2}{*}{ Sample } & \multicolumn{2}{|c|}{$\mathrm{ClO}_{4}^{-} / \mathrm{mg}$ in $1 \mathrm{~g}$ sample } & \multirow{2}{*}{ Main component } \\
\hline & Present method & JIS method & \\
\hline Go'ondama & $476.3 \pm 0.9$ & $471.6 \pm 4.3$ & $\mathrm{KClO}_{4}, \mathrm{Al}, \mathrm{S}$ \\
\hline Ignitor A†t & $454.4 \pm 1.6$ & $450.4 \pm 5.5$ & $\mathrm{KClO}_{4}, \mathrm{SrCO}_{3}, \mathrm{~S}$ \\
\hline Ignitor Błt & $347.6 \pm 2.3$ & $345.3 \pm 3.9$ & $\mathrm{KClO}_{4}, \mathrm{SrCO}_{3}, \mathrm{~S}$ \\
\hline Garlit & $559.4 \pm 2.7$ & $554.0 \pm 2.2$ & $\mathrm{NH}_{4} \mathrm{GlO}_{4}, \mathrm{NaNO}_{3}$ \\
\hline
\end{tabular}

$\dagger n=3, \alpha=5 \%$, $\dagger \dagger$ Of fusee for motorcars

滴定剤のゼフィラミンは安価であり，かつ純度も高 く, 煩雑な操作を必要とせずに定量でき, 又, 分析の自 動化も可能であり, 本法は過塩素酸イオンの定量法とし て有用性は高い. 又, 本電極は市販電極と比較して, 作 製が簡単で, かつ安価であり, しかもイオン交換液及び
内部参照溶液の補充, 交換などの必要もなく, 200 回以 上の滴定後も性能の劣化は認められなかった.

$(1982$ 年 2 月, 日本化学会及び日本分析化学会北

海道支部共催, 冬期研究発表会に拈いて一部発表)

\section{交献}

1) JIS K 4809, 火薬類分析試験方法 (1978).

2) B. J. Alley, H. W. H. Dykes : Anal. Chem., 36, 1124 (1964).

3) E. A. Burns, R. F. Muraca : Anal. Chem., 32, 1316 (1960).

4) I. Iwasaki, S. Utsumi, C. Kang : Bull. Chem. Soc. Jpn., 36, 325 (1963).

5) 山本勇麓, 小辻奎也, 絹脇晴一郎, 沢村紘明 : 日 化, 85, 59 (1964).

6) 大久保悌二, 青木交雄, 寺岡藤一：日化，89, 106 (1968).

7) R. J. Baczuk, W. T. Bottler : Anal. Chem., 39, 93 (1967).

8) 林田一良, 吉田仁志, 多賀光彦, 㱳目清一郎 : 分 化, 29, 304 (1980).

9) C. J. Coetzee, H. Freiser : Anal. Chem., 40, 2071 (1968).

10) N. Ishibashi, H. Kohara : Anal. Lett., 4, 785 (1971).

11) M. Sharp : Anal. Chim. Acta, 65, 405 (1973).

12) N. Ishibashi, A. Jyo, K. Matsumoto : Chem. Lett., 1973, 1297.

13) A. Hulanicki, R. Lewanddowski : Chemia analtyczna, 19, 53 (1974); \{Chem. Abstr., 81, $44848 \mathrm{j}(1974)\}$.

14) A. G. Wilson, K. H. Pool : Talanta, 23, 387 (1976).

15) M. Kataoka, T. Kambara : J. Electroanal. Chem., 73, 279 (1976).

16) K. Hiiro, A. Kawahara, T. Tanaka : Anal. Chim. Acta, 110, 321 (1979).

17) M. J. Smith, S. E. Manahan : Anal. Chim. Acta, 48, 315 (1969).

18) R. J. Baczuk, R. J. Dubois : Anal. Chem., 40, 685 (1968).

19) G. Eisenman : "Glass Electrode for Hydrogen and Other Cations”, p. 63 (1967), (Marcel Dekker, New York).

20) K. Srinivasan, G. A. Rechinitz : Anal. Chem., 41, 1203 (1969).

21) J. Kielland : J. Am. Chem. Soc., 59, 1675 (1937).

22) 加藤多喜雄, 沖中 裕, 堺 敬一：分化, 3, 231 (1954).

$$
\text { ss }
$$

Potentiometric precipitation titration of perchlorate ion with Zephiramine by the use of perchlorate ion-selective electrode with a liquid ion-exchanger in a poly(vinyl chloride) matrix. Tohru TAMURA* and Masamitsu KATAOKA** (*Scientific Crime Laboratory, Hokkaido Prefectural Police, Kita 2, Nishi 6, Chuo-ku, Sapporo-shi, Hokkaido, 060; **Department of Chemistry, Faculty of Science, Hokkaido University, Kita 10, Nishi 8, Kita-ku, 
Sapporo-shi, Hokkaido, 060)

The construction of a perchlorate ion-selective electrode and its application to potentiometric titration of perchlorate ion in the explosives with Zephiramine was described. The PVC matrix membrane containing $7.7(\mathrm{w} / \mathrm{w}) \%$ of tris-(bathophenanthroline)iron (II) perchlorate ion-associate was used as an ion-sensing membrane. The disk membrane was affixed to a PVC tube (I.D. $7 \mathrm{~mm}$ ) and silver-silver chloride electrode was used as the internal reference electrode. The composition of the cell including the present ion-selective electrode is as follows.

$\mathrm{Ag}-\mathrm{AgCl}$ electrode/reference solution, $50 \mathrm{mM} \mathrm{NaC1O}{ }_{4}$ in $50 \mathrm{mM} \mathrm{NaCl} / \mathrm{PVC}$ ion-exchange membrane//sample solution/SCE

The present ion-selective electrode exhibited a Nernstian response to perchlorate ion in the concentration range from $10^{-6}$ to $10^{-1} \mathrm{M}$. The potential of the electrode was constant over the $\mathrm{pH}$ range from 1 to 13 . Se- lectivity coefficients were evaluated and the electrode exhibited a good selectivity with respect to most common anions, while it showed some interferences with respect to periodate, iodide, and thiocyanate ion. The present ion-selective electrode was successfully adopted to the potentiometric precipitation titration of perchlorate ion with Zephiramine. It was revealed that the presence of equal or excess amounts of nitrate ion in the sample solution lowered the potential break at the end-point. However, the interference can be eliminated by the reduction of nitrate ion by heating with acetic acid and zinc powder.

(Received May 4, 1984)

\section{Keyword phrases}

potentiometric titration of perchlorate ion with Zephiramine; construction of perchlorate ion-selective electrode based on poly (vinyl chloride) matrix.

\title{
機器中性子放射化分析法による環境標準試料ムラサキイガイ中の 微量元秦の同時定量
}

\author{
鈴木 章悟， 平井 昭司®*
}

(1984 年 5 月 9 日受理)

\begin{abstract}
国立公害研究所で製作された環境標準試料ムラサキイガイ中の微量元素を機器中性子放射化分析法に より非破壊・多元素・同時定量した。分析法の信頼性を増すために，試料量（50〜250 mg）を变化さ せ，更に数回の繰り返し照射・測定を行った。試料は武蔵工大炉で短時間照射（気送管 2 分間）及び長 時間照射（中央実験管 5 時間）を行い，冷却時間を変えてそれぞれ 2 回ずつ $\mathrm{Ge}(\mathrm{Li})$ 検出器と 4096 千 ヤンネル多重波高分析器 (GAMA システム) で $\gamma$ 線スペクトルの測定を行い，約 50 元素を分析した. その結果, 20 元素の濃度が数\%の精度で定量され，そのほか 18 元素の濃度が多少精度が悪いが定量 できた。
\end{abstract}

\section{1 緒言}

近年, 環境問題の深刻化に伴い, 環境試料の分析の重 要性が認識されてきた. 環境試料の分析方法の開発及び 分析精度の向上のためには，成分の組成が確定された標 準試料が必要となる. 特に, 多元素・同時定量に有効な 機器中性子放射化分析法 (INAA) において元素組成が 正確に知れた標準試料を用いることは測定システムの校

* 武蔵工業大学原子力研究所 : 215 神奈川県川崎市 麻生区王禅寺 971
正及び 分析值の 精度を管理するうえで重要となってく る. 更に, 新しい分析手法の開発においても分析法の正 確さを検定するうえで必要となってくる.

このように環境標準試料の重要性が年々増大している 中で, 多くの機関で種々の標準試料が作製されている. 先般, 各種の環境標準試料を作製している1) 3)国立公害 研究所 (NIES) により海洋性生物の標準試料としてム ラサキイガイの標準試料が調製され，保証值の検討のた め種々の分析法での含有量の決定がなされている. 本研 究ではムラサキイガイ標準試料中の微量元素含有量を, 